\title{
Penerapan Model Pembelajaran Problem Based Learning Untuk Meningkatkan Hasil Belajar Siswa Mata Pelajaran PAK Di Kelas V SDN 003 Bintan Timur
}

\author{
Imayanti Nainggolan, $*^{1}$ Veronika Elli Lumbanraja, ${ }^{2}$ Efvi Noyita ${ }^{3}$ \\ Prodi PAK, STT Real Batam \\ Prodi PAK, STT Real Batam \\ Prodi PAK, STT Real Batam \\ imayantinaingg22@gmail.com
}

\begin{abstract}
The success of students in learning depends on the model of presentation of material by instructors who are fun, not boring interesting, and easy to understand by students. In 003 East Bintan Elementary School seen during the learning process, where in the learning process, the teacher still uses the lecture and writing method on the blackboard that does not actively involve students which will have an impact on student learning outcomes not in accordance with KKM. In general students must be able to think creatively, actively and critically. But what is often seen is that the teacher only gives explanations of the material, students only record what is conveyed by the teacher. The following things were observed by researchers. The author can conclude that, a new learning model can improve student learning outcomes is very important. Problem based learning learning model is a learning model that can improve student learning outcomes because problem based learning is made in groups to solve a problem making students more creative and even active to issue critical thinking among one another, so that students are not only passive hearing. Then the researchers formulated the problem as follows: what is the level of student success using the problem based learning model of learning? how to improve student learning outcomes by using the model of problem based learning? Researchers conducting research in this paper are PTK research (Classroom Action Research) using qualitative descriptive methods, namely by gathering sources in accordance with the topics listed above such as:Test cycle I and cycle II
\end{abstract} Keywords: Learning Model; Problem Based Learning, learning outcomes

\begin{abstract}
Abstrak
Dalam Berhasilnya peserta didik di dalam belajar bergantung pada model penyajian materi oleh pengajar yang menyenangkan, tidak membosankan menarik, dan mudah dimengerti oleh para siswa. Di Sekolah Dasar 003 Bintan Timur terlihat selama proses pembelajaran, dimana dalam proses pembelajaran, guru masih menggunakan metode ceramah dan menulis dipapan tulis yang tidak melibatkan peserta didik secara aktif yang akan berdampak dengan hasil belajar siswa tidak sesuai KKM. Pada umumnya siswa harus mampu berpikir kreatif, aktif dan kritis. Namun yang sering terlihat adalah guru hanya memberikan penjelasan materi, siswa hanya mencatat apa yang disampaikan oleh guru. Hal berikut yang diamati oleh peneliti. Penulis dapat menyimpulkan bahwa, model pembelajaran yang baru dapat meningkatkan hasil belajar siswa adalah sangat penting. Model pembelajaran problem based learning adalah model pembelajaran dapat meningkatkan hasil belajar siswa karena pembelajaran problem based learning dibuat dalam bentuk kelompok untuk memecahkan suatu masalah membuat anak didik semakin kreatif bahkan menjadi aktif untuk mengeluarkan pendapat berpikir kritis antar satu dengan yang lain, sehingga peserta didikpun tidak hanya pasif mendengar. Maka peneliti merumuskan masalah sebagai berikut: bagaimana tingkat keberhasilan siswa dengan menggunakan model pembelajaran problem based
\end{abstract}


learning? bagaimanakah cara meningkatkan hasil belajar siswa dengan menggunakan model pembelajaran problem based learning?. Peneliti melakukan penelitian dalam penulisan ini adalah penelitian PTK (Penelitian Tindakan Kelas) dengan menggunakan metode deksriptif kualitatif, yaitu dengan mengumpulkan sumber-sumber yang sesuai dengan pokok bahasan yang tertera diatas seperti: Tes siklus I dan siklus II

Keywords: Model Pembelajaran; Problem Based Learning, hasil belajar

\section{PENDAHULUAN}

Dalam pembelajaran Agama Kristen, seharusnya siswa dilatih berfikir, belajar aktif secara kritis dan kreatif untuk membuat keputusan, memiliki pola pemikiran analitis dan mampu bekerja sama, yang bertujuan untuk mengembangkan kemampuan peserta didik dalam menghayati serta mengamalkan nilai-nilai agama yang menyesuaikan kemampuannya dalam bidang ilmu pengetahuan, teknologi dan seni. Berdasarkan tujuan tersebut, maka dibutuhkan pengetahuan dan keterampilan yang memadai untuk mencapai hasil belajar yang diharapkan.

Namun ada berbagai permasalahan yang terjadi pada proses belajar mengajar di sekolah dasar SD 003 Bintan Timur, peserta didik kurang semangat dan kurang aktif dalam mengikuti pembelajaran. Hal tersebut disebabkan karena materi pembelajaran kurang dapat diterima secara maksimal oleh peserta didik, sehingga berdampak pada hasil belajar peserta didik di SDN 003 Bintan Timur masih tergolong rendah, hal ini terlihat dari banyaknya peserta didik yang hasil belajarnya kurang dari kriteria kelulusan minimal $(\mathrm{KKM})$ dan dinyatakan tidak tuntas pada mata pelajaran Agama kristen dapat diketahui bahwa nilai kognitif peserta didik masih rendah.

Kurangnya profesionalitas guru dalam menyampaikan materi diduga membuat siswa semakin tidak berminat untuk memperhatikan pelajaran, sehingga hasil pembelajaran tidak maksimal dan siswa dikatakan lemah dalam pembelajaran Agama kristen, yaitu kurang memiliki kemampuan pemahaman untuk mengenali konsep-konsep dasar pelajaran yang berkaitan dengan pokok bahasan yang sedang dibicarakan.

Oleh sebab itu harus ada perbaikan pembelajaran agar tujuan pembelajaran dapat tercapai. Salah satu upaya yang dilakukan untuk meningkatkan hasil belajar dapat melalui beberapa hal, diantaranya dengan penerapan model pembelajaran. Ada terdapat berbagai model pembelajaran, salah satunya adalah model pembelajaran Problem based learning.

\section{METODE}

Artikel ini disusun dengan menggunakan metode penelitian PTK melalui pendekatan kualiatatif. Cara yang dilakukan dalam penelitian ini adalah Tes. Tes adalah cara atau prosedur yang digunakan dalam pengukuran atau penilaian yang bergantung dengan tugas-tugas berupa soal pertanyaan mencakup pokok bahasan yang diajarkan. Adapun test yang digunakan dalam penelitian ini terdiri dari test akhir yang berjumlah 10 soal. 


\section{HASIL DAN PEMBAHASAN}

Istilah pembelajaran berhubungan erat dengan pengertian belajar dan mengajar. Belajar, mengajar, dan pembelajaran terjadi bersama-sama. Sementara itu pembelajaran adalah suatu usaha yang harus melibatkan dan menggunakan pengetahuan professional yang dimiliki guru untuk mencapai tujuan. Pembelajaran adalah proses interaksi peserta didik agar dapat belajar dengan baik. Menurut Rahil Mahyuddin, menyatakan bahwa pembelajaran adalah perubahan tingkah laku yang melibatkan keterampilan kognitif yaitu peguasaan ilmu dan perkembangan kemahiran intelek. ${ }^{1}$ Berdasarkan cara pandang pembelajaran di atas, pembelajaran pada hakikatnya adalah suatu usaha sistematik untuk menjadikan para pelajar agar bisa belajar.

Pembelajaran berbasis masalah yang berasal dari Bahasa Inggris Problem Based Learning (PBL) adalah suatu pendekatan pengajaran yang menggunakan masalah nyata sebagai suatu konteks bagi siswa untuk belajar tentang cara berpikir kritis dan memiliki keterampilan memecahkan masalah, serta untuk memperoleh keterampilan dan konsep yang esensial dari materi pelajaran. Menurut Delisle, PBL dikembangkan untuk membantu guru mengembangkan kemampuan berpikir dan keterampilan memecahkan masalah pada peserta didik selama mereka mempelajari materi pembelajaran. ${ }^{2}$ Sedangkan menurut Made Wane, problem based learning merupakan strategi pembelajaran dimana peserta didik belajar melalui permasalahan-permasalahan prkatis yang berhubungan dengan kehidupan fakta. ${ }^{3}$ PBL strategi pembelajaran yang berpusat dimana siswa bersama-sama memecahkan masalah dan merefleksikan pengalaman mereka, serta berdiskusi untuk memecahkan masalah. Karakteristik PBL belajar adalah didorong oleh tantangan, masalah terbuka atau realita, guru mengambil peran "fasilitator" belajar.

Dengan demikian, siswa dianjurkan mengambil tanggung jawab untuk kelompok mereka masing-masing mengatur dan mengarahkan proses pembelajaran dengan dukungan dari seorang guru atau instruktur

\section{Karakteristik Model Pembelajaran Problem Based learning}

Pembelajaran problem based learning memiliki karakteristik adalah sebagai berikut:

Pengajuan pertanyaan atau masalah, Pertanyaan dan masalah yang diajukan haruslah memenuhi kriteria sebagai Seperti autentik, yaitu masalah harus lebih berakar pada kehidupan dunia nyata siswa dari pada prinsip-prinsip displin ilmu tertentu yaitu masalah dirumuskan dengan jelas dan tidak menimbulkan masalah baru. Selanjutnya

\footnotetext{
${ }^{1}$ Mieke O Mendagi and I Nyoman Sudana Degeng, Model Dan Rancangan Pembelajaran (Malang: CV Seribu Bintang, 2019).

${ }^{2}$ Ika Maryani and Laila Fatmawati, Pendekatan Scientific Dalam Pembelajaran Di Sekolah Dasar: Teori Dan Praktik (Yogyakarta: Deepublish, 2018).

${ }^{3}$ Apri Damai Sagita Krissandi, B Widharyanto, and Rishe Purnama Dewi, Pembelajaran Bahasa Indonesia Untuk SD : Pendekatan Dan Teknis (Bekasi: Media Maxima, 2019).107
} 
mudah dipahami, yaitu masalah yang diberikan hendaknya mudah dipahami, dan luas dan sesuai dengan tujuan pembelajaran. Kemudian, tindakan pada pembelajaran berbasis masalah dicirikan oleh siswa yang bekerjasama dengan yang lainnya dalam kelompokkelompok kecil dua samapai dengan 4 orang. Dan yang terakhir, Menuntut pelajar untuk mendemostrasikan apa yang mereka telah pelajari dalam bentuk suatu produk atau kinerja.

\section{Kelebihan dan kekurangan problem based learning}

Pembelajaran promblem based learning memiliki kelebihan siswa lebih memahami konsep yang diajarkan antara ia yang menemukan konsep tersebut dan melibatkan siswa secara aktif dalam memecahkan masalah dalam memecahkan masalah dan menuntut keterampilan berpikir siswa yang lebih tinggi ${ }^{4}$ Kemudian menjadikan siswa lebih mandiri dan dewasa, mampu memberi aspirasi dan menerima pendapat orang lain, serta menanamkan sikap social yang positif dengan siswa lainnya serta pengkondisian siswa dalam belajar kelompok yang saling berinteraksi terhadap pembelajaran dan temannya, sehingga pencapaian ketuntasan belajar siswa dapat diharapkan. PBL diyakini pula dapat menumbuhkan kembangkan kemampuan kreativitas siswa, baik secara individual maupun kelompok, karena hamper di setiap langkah menuntut adanya keaktifan siswa

\section{Kekurangan promblem based learning}

Selain berbagai kelebihan tersebut, problem based learning memiliki beberapa kekurangan, yakni: Bagi siswa yang malas, tujuan dari penerapan PBL tersebut tidak dapat tercapai. Membutuhkan banyak waktu dan dana tidak semua mata pelajaran bisa diterapkan dengan metode PBL.

\section{Langkah-langkah penerapan Model pembelajaran problem based learning Orientasi siswa pada masalah}

Masalah atau pertanyaan yang diselidiki adalah masalah yang kompleks memiliki banyak penyelesaian dan sering kali bertentangan. Selama siswa melakukan penyelidikan akan mendorong untuk mengajukan pertanyaan dan mencari informasi. Guru akan bertindak sebagai pembimbing yang menyediakan bantuan, sedangkan siswa berusaha untuk bekerja mandiri atau bersama temannya.

\section{Mengorganisasikan siswa untuk belajar}

Pembelajaran ini membutuhkan pengembangan keterampilan siswa. Oleh karena itu, mereka juga membutuhkan dampingan untuk merencanakan penyelidikan mereka dan tugas-tugas pelaporan, yang meliputi kelompok belajar, mengorganisasikan siswa ke dalam kelompok belajar. setelah siswa diorientasikan kepada situasi masalah dan telah

\footnotetext{
${ }^{4}$ Nelly Wedyawati and Yasinta Lisa, Pembelajaran IPA Di Sekolah Dasar (Yogyakarta: Deepublish, 2019). 160
} 
membentuk kelompok belajar, guru dan siswa harus menyediakan waktu yang cukup untuk menyediakan sub pokok bahasa yang spesifik dan tugas-tugas penyelidikan, membimbing proses penyelidikan dapat dilakukan secara mandiri maupun kelompok, teknik penyelidikan meliputi

\section{Berhipotesis, menjelaskan dan memberikan pemecahan}

Pada tahap ini, guru mendorong mengeluarkan semua ide dan menerima sepenuhnya ide tersebut. Selanjutnya guru mengajukan pertanyaan yang membuat siswa memikikan kelayakan hipotesis dan pemecahan mereka serta tentang kualitas informasi yang telah mereka kumpulkan. Guru secara terus- menerus menunjang dan memodelkan pertukaran ide secara bebas dan mendorong mengkaji lebih dalam masalah tersebut jika dibutuhkan. Selain itu guru membantu menyediakan bantuan yang dibutuhkan siswa.

\section{Mengembangkan dan menyajikan hasil karya}

Guru meminta beberapa kelompok untuk mempresentasikan hasil pemecahan maslah dan membantu siswa menagalami kesulitan kegiatan ini berguna untuk mengetahui hasil pemahaman dan penguasaan siswa terhadap masalah yang berkaitan materi yang dipelajari

\section{Menganalisis dan mengevaluasi proses pemecahan masalah}

Guru membantu siswa mengalisis dan mengevaluasi proses berpikir mereka, disamping keterampilan penyelidikan dan keterampila intelektual yang mereka gunakan.

\section{Metode yang digunakan dalam penerapan model pembelajaran problem based learning \\ Diskusi kelompok kecil}

Teknik kelompok Buzz digunakan dalam kegiatan pembelajaran pemecahan masalah. sudjana menyatakan pelaksanaan kelompok kecil adalah sebagai berikut:

Pendidik, mungkin bersama peserta didik, memilih dan menentukan masalah atau bagian masalah yang akan dibahas dan perlu dipecahkan dalam kegiatan belajar. Pendidik menunjuk beberapa peserta didik untuk membuat atau membentuk kelompok kecil. Jumlah kelompok yang akan dibentuk dan banyaknya peserta dalam setiap kelompok kecil disesuaikan dengan jumlah bagian masalah yang akan bahas. Pendidik membagikan bagian-bagian masalah kepada masing-masing kelompok kecil. Satu kelompok membahas satu bagian masalah. Selanjutnya, pendidik menjelaskan tentang tugas kelompok yang harus dilakukan, waktu pembahasan biasanya 5-15 menit. Kelompok-kelompok kecil berdiskusi untuk membahas bagian masalah yang telah diberikan atau yang telah ditentukan. Para peserta didik dalam kelompok kecil itu memperjelas bagian maslah, serta memberikan saran-saran untuk pemecahannya. 


\section{Diskusi Panel}

Diskusi Panel adalah kegiatan bertukar pikiran atau bertukar pendapat dalam pegalaman antara tiga sampai enam peserta didik yang dipandu oleh seseorang ketua (moderator). ${ }^{5}$ Diskusi panel ini biasanya membicarakan suatu subjek tertentu, duduk dalam susunan semi melingkar, dipimpin oleh seorang moderator atau ketua kelompok.

\section{Menampilkan video}

Menampilkan video dalam pembelajaran problem based learning adalah salah satu cara untuk membuat siswa, aktif dan memiliki fokus yang besar, untuk memperhatikan video, sehingga melatih kemampuan Aspek afektif dan kognitif siswa. Keunggulan lain media video yaitu dapat menampilkan hal yang baru dan menarik bagi peserta didik seperti adanya animasi PAK, video fenemona Alkitab, sehingga dapat mengurangi kejenuhan dalam belajar konvensional dengan buku cetak. Media pembelajaran menggunakan video ini sangat baik untuk meningkatkan minat hasil belajar peserta didik dengan memperlihatkan suatu hal yang menarik dan dapat menambah daya ingat peserta didik pada materi pembelajaran. Sebagaimana yang dikemukakan oleh Sanaky bahwa dengan penggunaan media audio visual berbasis video ini juga mampu menambah daya tahan ingatan atau retensi tentang objek belajar yang dipelajari pembelajar ${ }^{6}$

\section{Hasil belajar siswa mata pelajaran PAK di kelas V SDN 003 Bintan dengan model pembelajaran problem based learning \\ Paparan data pelaksanaan tindakan siklus I}

Pada siklus ini peneliti melakukan pembelajaran satu kali pertemuan. Alokasi waktu 3 JP peneliti lakukan untuk menjelaskan materi kejatuhan manusia dari dosa dan pertobatan. Adapun tahap-tahap yang dilaksanakan dalam penelitian siklus ini terdiri beberapa tahap yaitu;

\section{Tahap Perencanaan}

Pada tahap ini hal-hal yang harus dipersiapkan oleh peneliti adalah:Melakukan kordinasi dengan Guru Agama Kristen SD 003 BintanMenyiapkan RPP yang akan digunakan untuk mengajar sesuai dengan pokok bahasan yaitu kejatuhan manusia ke dalam dosa dan pertobatan Menyiapkan materi.Menyiapkan lembar evaluasi untuk menguji tingkat pemahaman siswa setelah menerapkan model pembelajaran promblem based learning.

\footnotetext{
${ }^{5}$ Pupu Saeful Rahmat, Strategi Belajar Mengajar (Surabaya: Scopindo Media Pustaka, 2019). 105

${ }^{6}$ Farid Ahmadi and Hamidulloh Ibda, Media Literasi Sekolah : Teori Dan Praktik (Semarang: CV Pilar Nusantara, 2018).44
} 


\section{Tahap pelaksanaan}

Pada kegiatan Awal, peneliti memberi salam kepada siswa dan dilanjutkan untuk berdoa bersama-sama untuk memulai pembelajaran. kemudian peneliti mengabsen siswa dan menyampaikan tujuan pembelajaran. peneliti juga harus memastikan materi pembelajaran sudah dikuasai siswa. Pada kegiatan ini peneliti akan menjelaskan secara detail pengertian dan dasar kejatuhan manusia dalam dosa dan pertobatan. Setelah peneliti menjelaskan keseluruhan materi, peneliti memberi kesempatan kepada siswa untuk menyelesaikan permasalahan kasus yang diberikan.

\section{Kegiatan akhir}

Pada kegiatan akhir, peneliti melakukan tes akhir atau mengerjakan soal untuk mengetahui apakah ada peningkatan hasil belajar siswa setelah penerapan pembelajaran problem based learning. Untuk mengerjakan soal tersebut peneliti memberikan 20 menit waktu setelah itu, peneliti menyuruh siswa mengumpulkan lembar jawaban mereka, dan peneliti mengakhiri pembelajaran ditutup dengan berdoa.

\section{Data hasil observasi siklus I}

Setelah soal pilihan berganda yang sudah dilakukan pada siklus I adalah sebanyak 10 soal, maka berikut analisis hasil observasi siklus I

\begin{tabular}{|l|l|l|c|c|}
\hline No & \multicolumn{1}{|c|}{ Nama Siswa } & \multicolumn{1}{|c|}{$\begin{array}{c}\text { Nilai akhir } \\
\text { (KKM 75) }\end{array}$} & Tidak Tuntas & Tuntas \\
\hline 1 & Henokh & 80 & & $\checkmark$ \\
\hline 2 & Indah & 69 & $\checkmark$ & \\
\hline 3 & Anju & 60 & $\checkmark$ & \\
\hline 4 & Christina & 90 & & $\checkmark$ \\
\hline 5 & Elizabeth & 80 & $\checkmark$ & $\checkmark$ \\
\hline 6 & Elena & 67 & $\checkmark$ & $\checkmark$ \\
\hline 7 & Tiara & 68 & & $\checkmark$ \\
\hline 8 & Jonathan & 75 & & $\checkmark$ \\
\hline 9 & Natan & 80 & & \\
\hline 10 & Sry rahayu & 80 & & $\checkmark$ \\
\hline
\end{tabular}




\begin{tabular}{|l|l|l|c|c|}
\hline 11 & Laura & 65 & & \\
\hline 12 & Jumlah & 889 & 8 & 6 \\
\hline & Jumlah skor & & 6 & 6 \\
\hline
\end{tabular}

Rumus Hasil observasi siklus I

$\mathrm{P}=\frac{F}{N} \times 100 \%$

$\mathrm{P}=74.0833 \times 100 \%$

$\mathrm{P}=74.08 \%$

Maka nilai rata-rata siswa adalah $74 \%$

\section{Paparan data pelaksanaan tindakan siklus II}

Siklus ke II kemudian dilaksanakan setelah ada refleksi dan perbaikan nilai I. selanjutnya siklus ke II diadakan 1 kali pertemuan dengan alokasi waktu yang diadakan 3 JP. Sama halnya dengan siklus I, siklus ke II pun terdiri dari empat tahap lagi, antara lain adalah sebagi berikut;

\section{Tahap perencanaan}

Pada tahap siklus ke II ini sama hal nya dilakukan seperti siklus I adapun tahapannya yaitu peneliti harus kordinasi lagi dengan guru mata pelajaran PAK, kemudian peneliti kembali lagi menyiaplan RPP sesuai materi yang akan diajarkan dengan tema kejatuhan manusia ke dalam dosa, menyiapkan materinya sesuai pokok bahasan tersebut. Kemudian membuat lembar test siklus II untuk menguji tingkat pemahaman siswa setelah penerapan problem based learning, yang terakhir menyiapkan lembar observasi di siklus yang ke II untuk mengamati siswa di dalam kelas tersebut

\section{Tahap pelaksanaan}

Pada kegiatan awal ini peneliti memperhatikan siswa terlebih dahulu kesiapan siswa menerima pembelajaran. kemudian peneliti memberi salam kepada siswa, mengabsen siswa, dan menyampaikan tujuan pembelajaran supaya siswa ada gambaran secara umum mengenai materi yang akan diajarkan.Pada siklus yang ke II ini peneliti mengunakan metode pemecahan kasus dengan menonton video yang ditampilkan mengenai kejatuhan manusia kedalam dosa karena dapat membuat siswa lebih aktif, lebih memperhatikan dan berpikir kritis, sebelum penerapan problem based Learning dimulai. 
Hal ini dilakukan agar siswa dapat menjawab pertanyaan atau soal yang diberikan oleh peneliti.

\section{Kegiatan inti}

Pada kegiatan inti ini peneliti menjelaskan secara rinci atau menetail, kejatuhan manusia kedalam dosa, setelah itu peneliti memberi kesempatan kepada siswa untuk menyelesaikan permasalahan kasus yang diberikan oleh peneliti melalui video yang sudah di tonton.

\section{Kegiatan akhir}

Seteleh peneliti melihat siswa sudah mulai memahami materi yang disampaikan, kembali lagi peneliti memberikan tes akhir (Soal). Peneliti memberikan waktu untuk mengerjakan selama 20 menit. Setelah siwa sudah seleesai mengerjakan soal tersebut, peneliti mengumpulkan jawaban mereka. Kemudian peneliti memberi kesimpulan dari keseluruhan materi yang baru saja di pelajari, dan terakhir peneliti berdoa untuk mengakhiri kelas dan memberi salam kepada siswa.

Pada siklus II ini siswa lebih aktif dan semangat selama pembelajaran berlangsung. Kebanyakan peserta didik mampu menjawab pertanyaan yang diberikan oleh peneliti dengan benar, walaupun ada beberapa orang yang kesulitan menjawab pertanyaan

\section{Data Hasil Observasi Siklus II}

Setelah soal tes pilihan berganda yang sudah dilakukan pada siklus II adalah sebanyak 10 soal, maka berikut analisis hasil Observasi Siklus II.

Tabel hasil test siklus I

\begin{tabular}{|l|l|l|c|c|}
\hline No & \multicolumn{1}{|c|}{ Nama Siswa } & \multicolumn{1}{|c|}{ Nilai akhir } & Tidak Tuntas & Tuntas \\
\hline 1 & Henokh & 80 & & \\
\hline 2 & Indah & 80 & & $\checkmark$ \\
\hline 3 & Anju & & & $\checkmark$ \\
\hline 4 & Christina & 80 & & $\checkmark$ \\
\hline 5 & Elizabeth & 90 & & $\checkmark$ \\
\hline
\end{tabular}




\begin{tabular}{|l|l|l|c|c|}
\hline 6 & Elena & 80 & & $\checkmark$ \\
\hline 7 & Tiara & 80 & & $\checkmark$ \\
\hline 8 & Fridayanti & 80 & & $\checkmark$ \\
\hline 9 & Jonathan & 90 & & $\checkmark$ \\
\hline 10 & Natan & 80 & & $\checkmark$ \\
\hline 11 & Sry rahayu & 80 & & $\checkmark$ \\
\hline 12 & Laura & 80 & & \\
\hline & Jumlah & 980 & & \\
\hline & Jumlah skor : 980 & & & \\
\hline
\end{tabular}

Rumus hasil observasi siklus II

$\mathrm{P}=\frac{F}{N} \times 100 \%$

$P=81.66667 \times 100 \%$

$P=81.66 \%$

Berdasarkan hasil observasi diatas menunjukkan bahwa hasil belajar siswa meningkat dari hasil test pilihan berganda siklus I dapat diketahui rata-rata siswa pada siklus ke II sedangkan siswa yang tidak tuntas $0 \%$. Oleh sebab itu silus ke II menunjukkan siswa kelas V (Lima) mengalami peningkatan hasil belajar. Dan dengan demikian bahwa penerapan problem based learning dapat meningkatkan hasil belajar siswa kelas V SD 003 Bintan Timur.

\section{Hasil Penelitian Siklus I Dan Siklus II}

Pada siklus I dan siklus II setiap tahapan-tahapn sudah dillakukan dengan baik dan memberikan dampak dan perbaikan yang positif pada diri masing- masing siswa. Siswa mulai menjadi aktif, nilai siswa meningkat, dan lebih semangat mengikuti pembelajaran. dengan hal tersebut dapat diketahui bahwa penerapan problem based 
learning dapat meningkatkan hasil belajar siswa kelas V mata pelajaran PAK. Peningkatan hasil belajar tersebut dapat dilihat Pada table berikut:

Rekapitulasi hasil penelitian siklus I dan siklus II

\begin{tabular}{|l|l|l|c|}
\hline No & Kriteria & Siklus I & Siklus II \\
\hline 1 & Rata-rata kelas & $74,08 \%$ & $81,66 \%$ \\
\hline 2 & Peserta didik tuntas belajar & 6 orang & 12 orang \\
\hline 3 & Peserta didik belum tuntas & 6 orang & 0 \\
\hline
\end{tabular}

Dengan uraian diatas, penerapan model problem based learning dapat meningkatkan hasil belajar kelas V SD 003 Bintan Timur. Hal ini dibuktikan dengan adanya peningkatan hasil belajar dari test siklus I dan test siklus.

\section{KESIMPULAN}

Berdasarkan hasil Observasi yang peneliti lakukan selama ini, maka dapat diambil kesimpulan bahwa dalam proses pembelajaran problem based learning dapat meningkatkan hasil belajar siswa. Hal ini terlihat dalam pembelajaran siswa pada tahap pembagian beberapa kelompok dan dalam kelompok, siswa dituntut untuk aktif dalam proses pembelajaran seperti bertanya ataupun mengeluarkan pendapat sehingga melatih keberanian siswa. Hal ini menggambarkan adanya potensial siswa mampu berpikir kritis dan berdampak terhadap hasil belajar.

Dengan penerapan model pembelajaran problem based learning siswa meresponi dengan baik. Hal ini juga ditunjukkan dengan respon siswa baik dalam mengikuti pembelajaran maupun kerja sama dengan teman sekelompoknya sehingga dapat membantu mengerti konsep yang sedang diajarkan.

Dalam menggunakan model pembelajaran problem based learning hasil belajar siswa dari siklus I dan siklus II mengalami peningkatan yang sangat signifikan. Dari hasil observasi yang sudah diperoleh keberhasilan belajar anak semakin berkembang dengan seiring berjalannya waktu selama proses pembelajaran.

Maka penulis menyimpulkan bahwa penerapan model based learning dapat meningkatkan hasil belajar siswa. secara sederhana, yang dimaksud dengan hasil belajar tersebut adalah memiliki kemampuan yang diperoleh siswa setelah melalui kegiatan belajar mengajar. Perubahan yang terjadi pada setiap siswa yaitu mencakup tiga aspek yaitu aspek 
kognitif, afektif, dan psikomotorik. Aspek kognitif berkaitan dengan dengan hasil berupa pengetahuan dari yang tidak tahu menjadi tahu, dari yang belum paham menjadi paham. Sedangkan afektif berkaitan dengan sikap siswa, minat dan nilai yang dicapai. Kemudian aspek psikomotorik berkaitan dengan kemampuan fisik siswa.

Setelah penerapan model pembelajaran problem based learning siswa mampu bekerja sama dengan baik, mampu mengerjakan tugas dengan baik, dan meningkatkan hasil belajar siswa.

\section{KEPUSTAKAAN}

Ahmadi, Farid, and Hamidulloh Ibda. Media Literasi Sekolah: Teori Dan Praktik. Semarang: CV Pilar Nusantara, 2018.

Krissandi, Apri Damai Sagita, B Widharyanto, and Rishe Purnama Dewi. Pembelajaran Bahasa Indonesia Untuk SD : Pendekatan Dan Teknis. Bekasi: Media Maxima, 2019.

Maryani, Ika, and Laila Fatmawati. Pendekatan Scientific Dalam Pembelajaran Di Sekolah Dasar: Teori Dan Praktik. Yogyakarta: Deepublish, 2018.

Mendagi, Mieke O, and I Nyoman Sudana Degeng. Model Dan Rancangan Pembelajaran. Malang: CV Seribu Bintang, 2019.

Rahmat, Pupu Saeful. Strategi Belajar Mengajar. Surabaya: Scopindo Media Pustaka, 2019.

Wedyawati, Nelly, and Yasinta Lisa. Pembelajaran IPA Di Sekolah Dasar. Yogyakarta: Deepublish, 2019. 